\title{
GEORGE PO'T'TER, THE JUNTA, AND THE BEE-HIVE
}

(Continued from the previous issue)

VI

One of the best-known incidents in the history of the Bee-Hive is the reorganisation of 1870 , which enabled the Junta to put in their own nominee as editor. What has received far less attention is the way in which the process began in 1868 . The first intimation of this to the Bee-Hive's readers was the report of the half-yearly shareholders' meeting held on 29 May. After Potter had again stressed the effects of "the great depression in all trades", Troup, on behalf of the Directors, "laid a plan before the meeting, by which he thought that the paper could be more advantageously carried on in the interests of the shareholders". No details of this plan are given in the report; but from the ensuing discussion it is clear that it involved far-reaching changes, since Connolly, Whetstone, and others objected that "any alteration in the constitution of the paper" required the sanction of a speciallyconvened meeting. Having secured this respite, the shareholders then adopted a resolution, moved by Hartwell, which was obviously intended to provide an alternative solution to their problems - that arrangements should immediately be made for canvassing societies and holding district meetings to advocate the taking up of shares. ${ }^{1}$ But this was really a forlorn hope. At the special meeting, on 17 June, the discussion mainly centred round a proposal from the floor that a small committee should be elected to protect the shareholders' interests in the "impending negotiations". Eventually this was withdrawn, and the Directors were empowered to make "such alterations in the management and arrangements of the paper as would probably effect the object they all desired - increased circulation and influence, and the payment of a dividend on the shares". ${ }^{2}$

Although the nature of these "impending negotiations" was never disclosed in the Bee-Hive, the part played by Daniel Pratt during the

1 Bee-Hive, 6 June $\mathrm{I} 868$.

Bee-Hive, 20 June 1868 , 
next eighteen months leaves no doubt that he had provided further financial assistance, and in return had come to exercise a large measure of control over the paper. According to Henry Solly, writing of the autumn of r 869, "Mr. Daniel Pratt... having bought up most of the shares of the company, was then the virtual proprietor of the journal". ${ }^{1}$ That there was no intention in 1868 of closing down the Trades Newspaper Co. is clear from the reports of the shareholders' meetings, and in fact three more meetings of shareholders were held in 1869 . Presumably Pratt took up a sufficient portion of the unsold shares to give him a controlling interest in the Bee-Hive, on conditions which were laid down during the negotiations. However, Pratt seems to have preferred that this should not be made too public. His name was never mentioned in the Bee-Hive in connection with the reorganisation, the nearest approach being the report of his speech at the next Annual Soiree of shareholders and friends, when, called upon by the chairman, he remarked amid cheers that "he had rendered the conductors what little help he could in carrying on the paper". ${ }^{2}$ In October 1868 Hartwell printed without comment a letter ridiculing rumours of Pratt's close association with the Bee-Hive - rumours which the writer assumed to be based on the fact that his office and that of the paper were in the same building. ${ }^{3}$

The front-page announcement of the "new arrangements", on 4 July, rapidly passed over this aspect. "With the present number of this journal commence our new arrangements, the details of which, of course, concern only the shareholders, to whom they will be communicated in the usual way." But readers were left in no doubt about the resulting change in policy. The most prominent item in the announcement was what really amounted to a promise to cease from attacking the Junta, together with an appeal for united support:

"The mission of the Bee-Hive will be to draw together in one united body all those labouring in the ranks of industry; to heal those unhappy differences which have so long existed amongst the representatives of the working classes... This can only be done by mutual forbearance and conciliation; and we trust that all those in our ranks who, from whatever cause, may hitherto have differed from us, will now cordially unite in our support... As one means to the above end, personalities will be excluded from our columns..."

A later paragraph showed the intention of carrying further the policy,

1 These Eighty Years, I 893, Vol. II, p. 383.

2 Bee-Hive, 13 March 1869.

3 Bee-Hive, 3 r October 1868. 
already begun in a rather tentative way, of making the Bee-Hive a more respectable paper suitable for family reading - "freed as it will be from long sensational reports of occurrences that only serve to debase and demoralise the readers". The rest of the announcement dealt mainly with the Bee-Hive's "platform". This was to a large extent a reiteration of reforming measures which had already been advocated in its columns; but there were some significant, though slight, alterations in emphasis. For instance, efforts to improve wages and hours of labour were to be "combined with due consideration for the employer". While it was not new for a statement in the Bee-Hive to include the words: "The principle of arbitration in all trades disputes will be encouraged", this time they were followed by: "and no strike will receive support in these columns unless all reasonable means have first been tried to prevent it". And "employers as well as workmen" were invited to send in "communications on all matters relating to trade".

The issue of 4 July also carried a new sub-title: "A General Family Newspaper: The Recognised Organ of Industrial Interests". The same issue included three additional columns of advertisements from new advertisers - almost all of them publishing firms, which suggests that they were contacts of Daniel Pratt's. But apart from a few literary and dramatic reviews, a further reduction in the space given to the more lurid news items, and a favourable notice of the ASCJ. Annual Report, there was little immediate change in the Bee-Hive's contents. The most noticeable development was that references to the LWMA, which had already become less prominent during the preceding months, steadily diminished still further, and after 22 August almost completely disappeared. The issue of I August carried the last report of a meeting of the Association - a meeting which decided to call a Labour Parliament to select working-class candidates for the next general election; but the project was immediately abandoned, ostensibly through lack of time for making the arrangements.

This was the last attempt of the LWMA to play a leading part in the working-class movement. The Association had some noteworthy achievements to its credit - particularly the Trades Reform Demonstration of 1866 , the calling of the St. Martin's Hall Conference of 1867 , and the beginning of the agitation for working men M.P.'s; but these achievements had been very largely due to the energy and abilities of Potter and Hartwell, while Hartwell's reports of the Association's activities, which often appeared in other London papers besides the Bee-Hive, had helped to give it a reputation out of all proportion to its numerical strength or the standing of its members. At the height 
of the Association's success, in March 1867 , the total membership was only 60o. Among them were few really influential working men. Guile had withdrawn at the beginning of 1867 , Dunning was never a very active member; and apart from Connolly, Leicester, Whetstone, and the secretaries of four or five comparatively unimportant unions, the remaining members appear to have been men of little standing in the labour movement. ${ }^{1}$ Besides the individual membership, trade unions had been invited to affiliate from March 1867 , on payment of "I d. per head per annum", but by April i 868 only four of the smaller London societies were definitely reported to have become affiliated. ${ }^{2}$ Support was declining in I 868 - probably due as much to the loss of momentum in the Reform movement as to any other cause, since the political side of the Association's activities had been increasingly stressed after the failure of the St. Martin's Hall Conference committee and Potter and Hartwell might in any case have come to feel that the LWMA was losing its value as an instrument. But the complete cessation of its public activities was part of the price that had to be paid if the Junta were to be persuaded to support the Bee-Hive.

However, the Association was not immediately disbanded. Although in July i 869 George Howell referred to it as "the late London Working Men's Association", ${ }^{3}$ some three weeks later Potter wrote as president an open letter to the Comte de Paris about the latter's book on The Trade Unions of England, beginning his letter: "I am directed by the committee of the London Working Men's Association..."4 In August I 869 Potter attended the Trades Union Congress as representative of four organisations, the LWMA being one. ${ }^{5}$ But in July 1870 Hartwell in a letter to the Bee-Hive referred to it quite definitely as having by then ceased to exist. ${ }^{6}$ The most likely explanation is that the Association lingered on without much activity of any kind until soon after its main programme was merged in that of the Labour Representation League in August 1869, and was then allowed to lapse.

The one tangible result of the policy of attempted co-operation in I 868 was a jointly-convened meeting which discussed the Junta's Trade Union Bill. The Bee-Hive's first reaction to this Bill, in Nov-

\footnotetext{
${ }^{1}$ Henry Broadhurst, the stonemason, joined the Association in March 1867 , and became a committee member in the following month; but he had only recently come to London, and had not as yet become prominent in trade union affairs.

3 Bee-Hive, i I April I 868.

s George Howell to Auberon Herbert, 3 I July I 869 (George Howell's Letter Book, in the Howell Collection).

4 Bee-Hive, 2 I August I 869.

5 Bee-Hive, 4 September I 869.

${ }^{6}$ Bee-Hive, 9 July 1870.
} 
ember 1867 , had been hostile, on the grounds that it made no provision for offences by employers; to which Beesly had replied that the BeeHive's proposed amendments would be "suicidal". ${ }^{1}$ By the late summer of $\mathrm{I} 868$, Potter and Hartwell were prepared to withdraw their criticisms. Preliminary negotiations were protracted, and more than once seemed likely to break down; but eventually the meeting was called by leading members of the London Trades Council, the Conference of Amalgamated Trades, and the LWMA, for 14 October. When it was first suggested, in the Bee-Hive of 22 August, the proposal was that it should be formally sponsored by the three organisations, and this was probably the main reason for the difficulties in the early stages of negotiation. The notice calling the meeting, when at last it went out, was signed by members of each organisation as individuals. According to the Bee-Hive, the meeting was "conducted in the most calm and temperate manner, not an irritating or angry word occurring during the whole evening", while Beesly took the opportunity of expressing his "pleasure at the coalition of so many who had for some time for some reasons or other been disunited". ${ }^{2}$ The "coalition", as Beesly called it, was not as yet very firmly cemented. But the establishment of good relations was made easier when Hartwell, who must have found the restraints of the new regime irksome, left the Bee-Hive in December.

The immediate cause of Hartwell's split with his old colleagues was the 1868 general election. The manoeuvres during the months preceding this election - which was held in mid-November - also help to explain Pratt's increased interest in the Bee-Hive. In a situation in which the urban working men had been enfranchised by a Conservative government, the Liberals were making determined efforts to ensure that the new voters would be on their side. One result of this was the arrangement which provided the Reform League with an election fund of some $£ 2,000$, to be used in support of Liberal candidates in selected constituencies where there was now a large workingclass vote. George Glyn, the Liberal Chief Whip, was involved in the negotiations with Howell; and it was Glyn who was mainly responsible for the secret condition that none of the money should be spent on behalf of any candidate opposing a Liberal. But the bulk of the fund was supplied by Samuel Morley, the Nottingham hosiery manufacturer, who had already assisted the League with donations. ${ }^{3}$

1 Bee-Hive, 30 November and 7 December 1867.

Bee-Hive, 17 October 1868.

3 The whole affair of the "special fund" has been described in detail by Royden Harrison, in his "The British Working Class and the General Election of I868", in: International Review of Social History, Vol. V (1960), Part 3, and Vol. VI (196r), Part I. 
Morley was one of the leaders of the "advanced Liberal" Nonconformists. He was fully aware of the value of a close alliance with the organised working men, and had in fact shown some sympathy towards the demand for labour representation, seeing this as a means of strengthening "advanced Liberalism", while complete rejection of such claims might alienate working men from the Liberal party. In religion and in politics, Pratt shared Morley's views. They were both Congregationalists - which gave them an added link with Potter, who was also a Congregationalist; ${ }^{1}$ and the two of them were in fairly close touch through their work for such bodies as the Home Missionary Society and the Sunday School Union. Pratt's relations with the Bee-Hive were in many ways similar to Morley's with the Reform League. Nor did Morley himself neglect the Bee-Hive as a potential source of Liberal support.

During the election preparations, Potter sent out, obviously to selected Liberals, a printed leaflet headed "Private and Confidential". Its main contents took the form of a letter, stressing "the importance of the support of the Working Classes to the Liberal Party", and appealing for subscriptions to a circulation fund "for the purpose of helping the conductors of the Bee-Hive to extend the circulation of that paper among the industrial classes". It was intended, Potter continued, "to publish a series of special articles upon political subjects of the deepest interest, and circulate them widely among Working Class Voters, to guide them at this important crisis in sustaining the LIBERAL PARTY at the coming election". Then followed a list of those who had already subscribed, headed by Pratt and Morley, each of whom had given $£ 100 .{ }^{2}$ The total was already more than $£ 440$; and presumably more was collected. The fund was never mentioned in the Bee-Hive. But the promised articles duly appeared, written by a contributor who called himself "Plain Dealer".

In October, Daniel Pratt was adopted as Liberal candidate for Lymington. Potter was the principal supporting speaker at his first meeting, and spent much time in Lymington during the campaign, addressing at least one meeting each week on Pratt's behalf. ${ }^{3}$ At one of them another speaker was J. M. Hare, an old newspaper associate

\footnotetext{
1 Potter had not so far given the impression of being a man whose public life was very much influenced by his religious views. But in 1867 he had aroused some comment by attending a meeting of trade unionists called by Morley to consider "The Working Classes and Religious Institutions" (Commonwealth, 6 and 27 April i 867).

${ }^{2}$ A copy of this leaflet eventually came into the possession of John Burns, who kept it inside one of his duplicate volumes of the Bee-Hive. It is now in the Burns Collection.

${ }^{3}$ Lymington and Isle of Wight Chronicle, 23 October to 13 November 1868.
} 
of Pratt's; and Hare introduced Potter, who followed him on the platform, in terms which were intended to be highly complimentary: "Ask Samuel Morley, and other great men, his character, and they will tell you they depend in a great measure on George Potter for keeping the working men of England right. Not only were these meetings reported in the Bee-Hive, but in one issue Pratt was actually recommended to the electors in a leading article, largely quoted from the Cbristian World. ${ }^{1}$ Only Hartwell, who at the beginning of October had agreed to stand for Stoke-on-Trent as Independent Working Men's Candidate, was given anything like a comparable amount of space. In spite of the Bee-Hive's changing attitude towards the Junta and their followers, there was no support for Odger in his attempt to contest Chelsea, and no mention of Howell's candidature at Aylesbury or Cremer's at Warwick.

Potter's personal appearances were confined to Lymington - a small and Tory-dominated borough where Pratt had little prospect of success. Although Potter might have made far more impact on the new electors in Stoke, where memories of the 1865 puddlers' strike were still fresh, it was very noticeable that he made no attempt to assist Hartwell. In fact, of the London men only Thomas Connolly, who was later thanked by Hartwell for his unpaid assistance, did anything on his behalf. Nor was this Hartwell's only disadvantage. The working men of the Potteries were not impressed when he asked them to "support the interests of Labour - which he regarded as being superior to either Liberal, Conservative, or any party interest". ${ }^{2}$ The local trade union leaders had already committed themselves in support of the two Liberals who were in the field before Hartwell arrived, and even his own election committee - men who had invited him in the first place on the grounds that they wanted an independent candidate proved so half-hearted that no funds were collected locally. Although some E.5 was collected through the Bee-Hive, Hartwell eventually found himself unable to raise the $£_{1}$ oo which had to be deposited with the returning officer, and just before the election he withdrew, accepting the offer of $£_{280}$ towards his expenses from his Liberal opponents. The transaction was given a good deal of publicity, and Hartwell was much criticised. As usual, he hit back, issuing a "vindicatory statement" (passages from which were reprinted in the BeeHive $)^{3}$ and replying to press comment. In one letter to the Standard

${ }^{1}$ Bee-Hive, 24 October 1868 . Potter distributed 250 copies of this issue to the workingclass electors at Lymington (Lymington and Isle of Wight Chronicle, 3o October I 868).

2 Staffordshire Sentinel, 17 October 1868.

2 Bee-Hive, I 2 December 1868. 
he asserted that his lack of support in Stoke had been due not only to local intrigues and the treachery of members of his committee, but also to the opposition of working-class leaders in London "who, when the time of trial came, found it more profitable to give their personal aid to candidates with long purses". ${ }^{\text {Th }}$ This marked the end of the working partnership between Potter and Hartwell which had done so much to shape the distinguishing characteristics of the Bee-Hive since 1863 . In the next issue it was announced that Hartwell had "ceased to be connected with the Editorial or Literary departments of the Bee-Hive".

From the end of 1868 until his death in 1875 , Hartwell was engaged in what he once described as "precarious employment" as a reporter to the London press. It is even doubtful whether any of the $£ 280$, which was paid over without his consent to members of his Stoke committee, was ever used to reduce his debts; and in 1869 he was forced into bankruptcy. At one time he was claiming the right to vindicate his character before a working-class committee of enquiry, but nothing came of this, and in his last years he seems to have been fully occupied with the problem of earning a living. ${ }^{2}$ It was something of an anti-climax to the thirty-odd years of service he had devoted to the labour movement. As editor of the Bee-Hive, he had given the paper a vitality and an appeal that were rare in the working-class journalism of the period. With a true journalist's appreciation of the varying news-value of contemporary events, he had brought into prominence week after week those topics that were coming to be uppermost in the minds of his readers; while on some questions, such as the "direct representation of labour", he had given a lead to working-class opinion. It is true that the Bee-Hive had included much personal abuse, especially at the time of the quarrel with the Junta, and that the sense of urgency in Hartwell's editorials and articles was often matched by all the appearance of haste in putting together the contents of the paper. But his approach was always that of a working man who was passionately concerned with the problems facing his own class. The Bee-Hive was still to undergo many changes after Hartwell left; but it was never again to give quite the same impression of being almost entirely written by working men for working men.

\section{VII}

The editorship was discussed at the next shareholders' meeting, in January 1869 . It was agreed that "a committee of three should be

1 Standard, 17 December 1868.

${ }^{2}$ See Bee-Hive, 27 February and ig June 1869, and 6 November 1875. 
appointed to work the paper", and the Directors were empowered to make the necessary arrangements. ${ }^{1}$ Whether they in fact did so is uncertain; but it is clear that until the further reorganisation of February 1870 , the editor - or at least, the editor-in-chief - was Potter himself. Under him, the development towards a more sober and decorous type of journal was continued. A larger number of signed contributions appeared during 1869 , but they made comparatively dull reading, as did Potter's editorials. Nevertheless, at the next Annual Soiree J. M. Hare declared that the Bee-Hive "was greatly improved during the last few months, since it had come more directly under the conduct of Mr. Potter".2

Three new organisations set up in 1869 - the Workmen's Emigration Society, the National Education League, and the Labour Representation League - provided much material for the Bee-Hive. The emphasis now given to emigration schemes and to educational reform reflected two of Pratt's main interests. The former also provoked some harsh criticism from the Land and Labour League. This body - "the nearest approach to a Socialist body of any substance" in England at that time $^{3}$ - was yet another of the new organisations of 1869 . The main item on its programme was the nationalisation of the land, the second was "home colonisation"; and the "emigrationists" were attacked as "half-hearted reformers" whose efforts were preventing a more radical approach to the land question. ${ }^{4}$ Potter was firmly on the side of the "emigrationists", on the land question itself he preferred the policy of the far more respectable Land Tenure Reform Association, and there was no room for the Land and Labour League's views in the Bee-Hive. Potter had attended the League's inaugural meetings, but his main contributions had been an unsuccessful attempt to tone down some of the resolutions, and the assertion that "they now had a government which would respectfully listen to the representatives of working men". ${ }^{5}$ This hopeful view of the new Liberal government may also be taken as summing up the Bee-Hive's attitude.

In the issue of 30 January an editorial by Potter had referred back reproachfully to the events of 1867 - "Personally, we believe we were badly treated... stigmatised, suspected, and leagued against"; but the main burden of the editorial was a plea for united effort to secure the

\footnotetext{
1 Bee-Hive, 30 January 1869.

a Bee-Hive, I3 March 1869.

${ }^{3}$ G. D. H. Cole, History of Socialist Thought, Vol. II (1954), p. 38 I.

"Royden Harrison, "The Land and Labour League", in: Bulletin of the International Institute of Social History, Vol. VIII (1953), No. 3.

${ }^{5}$ Reynolds's Newspaper, I7 October 1869; National Reformer, 24 October 1869.
} 
full legalisation of trade unions. This was translated into action later in the year. Soon after the Commission's reports had appeared, the Conference of Amalgamated Trades decided to sponsor a new Bill drafted by Harrison on the basis of the minority report. ${ }^{1}$ Thomas Hughes and A. J. Mundella agreed to introduce it in the House. Potter called two meetings of delegates from those London unions that had been represented at the St. Martin's Hall Conference; and the second meeting, which was attended by Hughes and Harrison, not only agreed to support the Bill, but also decided to accept Applegarth's invitation to adjourn their meeting and join in that called by the Conference of Amalgamated Trades for the following week - "in order to secure united action". ${ }^{2}$ At Applegarth's meeting, on 28 April, five of those present were elected to make up a committee of ten with Applegarth, Allan, Odger, Coulson and Guile, for the purpose of arranging further meetings and lobbying M.P.'s. Among the five were Potter, Dunning and Henry Broadhurst. ${ }^{3}$ At the next meeting of the Conference - which was not held until i 8 February 1870 - it was decided that the five delegates who had been elected to the joint committee should "form part of the Conference in future". Potter played an active part as a member of the Conference until it was dissolved just over eighteen months later.

At the same time that he was coming to terms with the Junta, Potter was also making efforts to tone down his reputation as a working-class militant. In February, at the request of Samuel Morley, he had called together a social gathering of working men to be addressed by the Rev. Christopher Nevile on "The Political Future of the Working Classes". Morley, from the chair, pleaded for "more sympathy between classes", and Potter took the opportunity of declaring that "working men needed a leader like Mr. Morley, in whose hands they felt they might safely confide their grievances". ${ }^{4}$ Potter's approving comments on Morley's views in his next editorial were among several such references to Morley which appeared in the Bee-Hive at about that time. In July Marx wrote to Engels complaining that in the Bee-Hive "all that is anti-bourgeois in reports of our meetings is now censored"; and his explanation of this was: "The Bee-Hive is now

${ }^{1}$ Minutes of the Conference of Amalgamated Trades, 5 and 12 April 1869 (Webb Collection).

2 Bee-Hive, 17 and 24 April 1869.

${ }^{3}$ Bee-Hive, x May r 869. In July Hughes and Mundella agreed to withdraw the Bill on the understanding that the government would at once introduce a measure granting temporary protection to trade union funds, and that this would be followed by a full-scale Trade Union Bill in the near future.

${ }^{4}$ Bee-Hive, 6 February 1869. 
under the control of Samuel Morley". Engels replied: "It is truly a disgrace, that after nearly forty years of a political working-class movement in England the only workers' paper which exists should be bought up by a bourgeois like S. Morley". ${ }^{1}$ Marx was not so far wrong, since Pratt obviously looked to Morley for a lead; and Marx himself seems to have realised that Morley's position in relation to the Bee-Hive was that of patron rather than proprietor. ${ }^{2}$ But from this exchange of letters, and similar references later in the correspondence, arose the legend that it was Morley and not Pratt who had bought control of the paper. ${ }^{3}$

Marx was soon to have further cause for complaint, as the next stage in the Bee-Hive's reorganisation was carried through. This development was closely connected with the formation of the Labour Representation League. In the summer of 1869 , three groups - one led by Applegarth, Allan, Odger, Howell, and the old Owenite journalist Lloyd Jones, another consisting mainly of Cremer and some fellow-members of the International, and a third centred round Potter were all aiming to establish new political associations "for the return of working men to Parliament". "It was Richard Marsden Latham, a Radical barrister and a member of Potter's group, who took the initiative in bringing them together. The negotiations required at least three dinner parties, at Latham's house, and several more formal meetings; but eventually, in spite of "sharp words" on one occasion between Odger and Potter, and the initial reluctance of Allan, Applegarth and Lloyd Jones to agree to amalgamation, the Labour Representation League was established on I I August. The "principal duty" of the League was defined as "securing the return to Parliament of qualified working men"; it was also to support other candidates recognised as working-class sympathisers, and to "aid in promoting all such political, industrial and social questions as involve the well-

Marx to Engels, 29 July I869; Engels to Marx, 30 July I 869 (MEGA, Vol. IV, pp. 214215).

${ }^{2}$ In the declaration denouncing the Bee-Hive, which appears in Marx's own handwriting in the General Council Minutes of 17 May 1870 , one paragraph originally referred to the suppression of "such resolutions as might displease its proprietors". Marx crossed out "proprietors" and substituted the word "patrons". (I am indebted to Dr. Royden Harrison for this information.)

${ }^{3}$ This is accepted by Dona Torr in an editorial note on the Bee-Hive in the translated selection from the Marx-Engels correspondence - "In I 869 it was bought by Samuel Morley" (Marx-Engels Correspondence, 2nd edition, 1943, p. 168).

- The Reform League had been dissolved in March. Geotge Howell left a detailed account of the developments of the next few months in his Ms. Notes and Memoranda as to the History of this League (the L.R.L.) (Howell Collection). 
being of the working classes". ${ }^{1}$ Latham was president, Lloyd Jones secretary, and Allan treasurer. The thirty-two members of the first Executive Committee included all the important leaders of the London trade unionists.

At some time during the negotiations the idea of making the BeeHive the organ of this "united front" must have been raised. This involved another round of negotiations, again with Latham at the centre. There is little record of what took place, but we know from George Howell's letter-book that early in September he accepted an invitation to lunch with Potter, Latham and Pratt - obviously to discuss the Bee-Hive; and further meetings to discuss the paper's future were held at Latham's house. ${ }^{2}$ The weakness of Potter's position was demonstrated by the results. Not only was the Bee-Hive changed, in format and in contents, into a quite different paper from the one he had founded, but for the first time he was forced to accept a clearly subordinate position in the day-to-day running of the paper. The really decisive move was the appointment of the Rev. Henry Solly to act with Potter as joint editor. Potter would no doubt have welcomed assistance with his editorial duties; but the joint editorship was more a concession to appearances than a reflection of the actual situation, and although this was never explained in so many words to the Bee-Hive's readers, behind the scenes it was fully understood that Solly was to be editor-in-chief.

Henry Solly was the Unitarian minister who had been instrumental in founding the Working Men's Club and Institute Union in 1862. He was much respected by the Junta, who knew that one of his great ambitions was to edit a journal for working-class readers. According to Solly's own account in his autobiography, it was Odger who approached him in the autumn of 1869 and "sounded me about taking part in editing the Bee-Hive newspaper". ${ }^{3}$ Odger introduced Solly to Pratt, "the virtual proprietor", and to Latham, and "an arrangement was entered into" whereby Solly was to receive $£_{2}$ a week for his services. Solly says nothing to suggest that anyone except Pratt and Latham needed to be consulted; but the further reorganisation was also discussed by the Trades Newspaper Company's shareholders. Two meetings were held - on 8 November and 2 Decemberto "consider proposals affecting the future of the Bee-Hive", which

\footnotetext{
1 Bee-Hive, 2 I August I869.

${ }^{2}$ George Howell to George Potter, 3 September 1869; George Howell's Diary, 28 and 3I December I 869 (Howell Collection).

${ }^{3}$ Solly devotes nearly four pages of his autobiography (These Eighty Years, Vol. II, pp. $383-386)$ to an account of his connection with the Bee-Hive.
} 
were confirmed at the second meeting. ${ }^{1}$ Potter then wrote to Solly, enclosing "a circular showing our contemplated alterations", and accepting the proposed working arrangements: "There is nothing that I can see to prevent our working together as suggested by you."2

On 4 December it was announced in the Bee-Hive that the paper would soon be "launched afresh", with the price reduced to one penny. In the next issue appeared a Notice to Working Men, outlining the future programme, and stressing the achievement of the "united front": "The leaders of the various organised sections of working men now stand together to do battle, side by side, for the benefit of their class." It was in the issue of s February, which carried a revised version of this Notice, that readers were informed for the first time of Solly's future connection with the paper. A week later, a long editorial explained that Solly and Potter would share the functions of editorship, and concluded a eulogy of Solly by correctly forecasting the tone of the new Bee-Hive: "Readers may expect from his pen a series of papers of an informing and elevating tendency, on points affecting their higher nature in its moral and intellectual development, as well as those which have more immediate reference to their material interests, social advancement, and domestic well-being."

As far as policies were concerned, the programme suggested little in the way of new departures - though Solly's influence was apparent in the second version, which included "revision of the licensing system" as an added aim, and "reports on Working Men's Clubs" and "information on the past history of the working classes" among future contents. Both versions gave the names of members of a new Consulting Committee, which in the second numbered eighteen, including all five of the Junta, Howell, Dunning, Latham, and four relatively obscure men who had been members of the last Board of Directors. But there was one very significant change between December and February. The original announcement had given much prominence to a decision of the shareholders that "additional capital of $£$ I 0,000 be raised" by the issue of new $£$ I shares, in which endeavour they would have "the active assistance of the Labour Representation League". In February, this section was entirely omitted.

There is no evidence that capital was raised in any other way; but this scheme must have been abandoned, and the change of plan marked the end of the Trades Newspaper Co. as an active concern.

1 These meetings were announced in the Bee-Hive, but no report was published.

${ }^{2}$ George Potter to Henry Solly, i I December I 869 (Solly Collection, British Library of Political and Economic Science). 
No further meetings of shareholders were reported, nor was there any further reference to the company in the columns of the Bee-Hive. It retained at least a semblance of life until March i 873, when "Printed and Published by George Potter for the Trades Newspaper Co., Ltd." at length ceased to appear at the bottom of the back page, and it remained on the register, along with many others that had similarly ceased to function, until $\mathrm{I} 88 \mathrm{2.}{ }^{1}$ But it is significant that Potter's view, in spite of the meetings held in I869, appears to have been that the real ending of the company came when the "new arrangements" were made with Pratt in the previous year, since in reply to an enquiry from the Registrar in 1878 Potter stated: "The Trades Newspaper Co. ceased to exist in $1868 \%{ }^{2}$ Pratt had certainly been controlling shareholder in $1868-9$. From then on, his position appears to have been that of sole proprietor.

From the first issue of the penny Bee-Hive, on ig February 1870 , it was obvious that the paper had indeed been "launched afresh". Its very appearance was radically altered; and both in format and in contents it had become a somewhat peculiar mixture of newspaper and magazine. "Trades intelligence" still had an important place, there were fairly full reports on other sections of the working-class movement, and as the year went on signed articles included eight on "Education in Switzerland" by Applegarth, and eight on "Arbitration Between Capital and Labour" by William Owen of the Potteries Examiner. But the general tone of the new Bee-Hive was inevitably set by Solly's editorials and leaders, and by the new features which he introduced into the paper.

Solly had flung himself into the work with great enthusiasm. Potter retained his post as manager, and was still responsible for the collection and presentation of trade union news; but on the editorial side, as Solly's autobiography makes clear, he was little more than an assistant to Solly. ${ }^{3}$ One of Solly's innovations - suggested to him by Pratt - was a series of "Letters to Statesmen", mainly urging the adoption of various measures of mild social reform. Another, headed

\footnotetext{
1 The company was eventually dissolved by notice in the London Gazette of 7 March I 882, "under Cl. 7 (4) of the Companies Act of 1880 " - which gave the Registrar power to announce the dissolution of companies which had ceased to send in returns.

2 In the file of the Trades Newspaper Co., Ltd.

${ }^{3}$ Potter now devoted some of his time to writing articles for the Contemporary Review, three appearing in June, August and November 1870, and one in the following February. Although they dealt with trade union and industrial problems, these articles contained scarcely a word to which the Junta could have had any objection.
} 
"Club Room Chat", recorded in dramatic form the discussions at a Working Men's Club, where a "Thoughtful Person" (representing Thomas Hughes) gave good advice to the members. Solly also, during the year, included four of his own serial stories. These were intended to "awaken a greater interest in historical subjects"; but they had no great literary merit, they were interrupted by passages of moralising, and none had more than the slightest relevance to the problems of a working man in Britain in 1870 .

For the rest, Solly did of course support the claims of moderate trade unionism; he campaigned against the Truck system in Scotland and South Wales; and his sympathy for the poorer classes in general, not just for those in the ranks of organised labour, led him more than once to draw attention to the needs of the unskilled and unorganised workers. But his concern for cheap patents to help poor inventors, better safeguards against railway accidents, remedies for abuses in the Church, and innumerable similar causes, greatly diminished in emphasis what was specifically working-class in the Bee-Hive's programme. His great hope was for "a true national union of all classes", and this made him unwilling to criticise employers except in the mildest terms. ${ }^{1}$ Moreover, in spite of his genuine desire to be regarded as a "brother working man", Solly could never of course write like Hartwell, or even Potter, as one working man addressing others. In the last editorial of the old Bee-Hive, Potter had described Solly as one who supported working-class movements "without airs of patronage"; but when so much of Solly's writing took the form of advice to working men, the best intentions could not prevent the result from sounding patronising.

It is an illuminating comment on the social and political aspirations of the main working-class leaders that this should have been the outcome of a reorganisation which was to have made the Bee-Hive "the exponent and defender of working men's rights and interests, and the recognised teacher of those important public duties which their newly acquired political power has imposed upon them". ${ }^{2}$ The Junta could not have foreseen the full extent of the change when Solly was brought in as chief editor. Solly was obviously given a very free hand, with little interference either from Pratt or from the Consulting Committee; and he had no hesitation about including members of the

1 A chatacteristic comment, made at a time when wage claims by the cotton operatives were being rejected, was: "Masters as well as men should honourably and earnestly apply their minds and hearts to the discovery of some method and some terms on which they may dwell together amicably, work together harmoniously, and share with one another on a just and equitable footing" (Bee-Hive, 21 May 1870).

${ }^{2}$ Bee-Hive, I I December I869. 
Junta among those to whom he offered advice and even mild reproof. ${ }^{1}$ Nevertheless, it was their policy of moderation which had largely determined the nature of the change, and in the circumstances of 1870 , while they waited for the government to make up its mind about the provisions of its forthcoming Trade Union Bill, they seem at first to have preferred the innocuous tone of the new Bee-Hive to its earlier working-class militancy.

Naturally enough, some of the paper's old supporters were alienated by the change. ${ }^{2}$ But any loss of support was more than offset by the reduction in price, the backing of middle-class Liberals, and the renewed efforts that were made to extend the circulation. ${ }^{3}$ In April it was announced that the circulation had "nearly doubled" since the new series commenced - although unfortunately with no indication of the actual figures. The task of introducing the Bee-Hive to new working-class readers was undertaken mainly by Potter, who, relieved of most of the burdens of editorship, revived in a more sustained way his earlier practice of touring the provinces and setting up committees to foster sales. In October Potter negotiated an agreement with the newly-formed Amalgamated Association of Miners, who appointed agents to sell the Bee-Hive in return for a weekly allocation of space. Solly meanwhile made use of his Club contacts, and he also persuaded the annual conference of the National Association of Ironworkers to pass a resolution urging all their members to support the paper.

On the whole, the period of Solly's editorship appears to have been a time when working-class support for the Bee-Hive was on the increase. But one working-class organisation - the International - now put on record a formal repudiation of any connection with the paper. When the reports of the General Council's debates and resolutions on the Irish question were first mutilated, and then (while Solly expressed unqualified approval of Gladstone's "just and comprehensive" measures) were omitted altogether, Marx at last came to the conclusion that "we would be better without its publicity than with it". This put Applegarth and Odger in a very awkward situation. Although Odger had given up his presidency, and in Marx's view they had both become "possessed with a mania for compromise and a thirst for respectability", ${ }^{4}$ they were still members of the General Council, and Applegarth had demonstrated his concern for the International

${ }^{1}$ E.g., Solly's comments on the "bad taste" of Odger's references to the Liberals during his Southwark election campaign (Bee-Hive, s March i 870.)

' See, e.g., a letter from F. J. Burgess (one of the original seven Directors) in the Bee-Hive of 13 August 1870 .

${ }^{3}$ The list of middle-class supporters (regularly published by Solly) had grown by the autumn of 1870 to sixty-seven well-known names, just over half of them Liberal M.P.'s ${ }^{4}$ Marx to Engels, s April r $86_{9}$ (MEGA, Vol. IV, p. 177). 
by attending the Basle Congress in 1869 . But they also, as Marx and others on the General Council pointed out, "belonged to the Bee-Hive committee". The ensuing discussion showed how little control they really had over the new Bee-Hive. Applegarth sat opposite Marx - "with a diminished head", as Marx described it to Engels - while Marx denounced the Bee-Hive as a paper "sold to the bourgeoisie", which "preached harmony with the capitalists". Applegarth "thought he had a bad case in hand. Some time ago a change of proprietorship had occurred, and the paper had been offered to the Labour Representation League to manage it as they liked. He had thought it might yet be a good paper and through that his name had got on the Committee, but he valued his connection with the International far too much not to cheerfully resign his post on the Bee-Hive." It was Applegarth who then proposed that Marx should "draw up a declaration for publication". This declaration, describing the Bee-Hive as "the organ of a capitalist fraction who want to keep the proletarian movement in their leading strings", was unanimously approved at the next meeting. ${ }^{1}$

In the second half of 1870 , the Franco-Prussian war, and more briefly the excitement aroused by the London School Board elections, took precedence over all other features of the Bee-Hive. On the war, Solly took from the beginning a strongly pro-German line. Workingclass sympathy for the defeated French, and for their efforts to reestablish a Republic, showed up with increasing emphasis in the news columns; and the Labour Representation League's deputation to Gladstone in September, asking for recognition of the French Republic and endeavours to bring about peace "with no annexation of territory", included Potter and almost half the members of the Consulting Committee. But this in no way influenced the Bee-Hive's editorial views - in fact, Beesly's pamphlet, $A$ Word for France, was greeted with the only editorially-sponsored attack on Beesly that ever appeared in the Bee-Hive. ${ }^{2}$ When it came to the School Board elections, there was no divergence between Solly and the Labour Representation League, whose candidates were strongly supported. Potter, standing for Westminster, came forward as "one who would never exclude religion from the schools", believing in "Bible reading without sectarian teaching"; and in face of surprised comment in the daily papers, he brought in Daniel Pratt to help refute the view of a sudden conversion. $^{3}$ But Potter was unsuccessful, as were all the other League candidates except Benjamin Lucraft.

${ }^{1}$ General Council Minutes, 26 April and 17 May 1870; Marx to Engels, 28 April 1870 (MEGA, Vol. IV, p. 3I2).

3 Bee-Hive, $I$ and 8 October 1870.

${ }^{3}$ Bee-Hive, 19 and 26 November 1870 . 
In his autobiography, Solly suggests rather vaguely that the circulation continued to increase throughout the year. Against this, however, must be set the fact that advertisers were taking less space; while Solly's salary of $£_{2}$ a week, although guaranteed by Pratt, was expected to come out of the paper's profits. There was a further drain on the Bee-Hive's resources through the dishonesty of a salesman, whose thefts were not immediately detected. But there were more decisive reasons for the next change in the conducting of the Bee-Hive. As Solly puts it:

"The proprietor became unfortunate in his own special business, which had to go into liquidation... The difficulty of working with a colleague (who I found afterwards had, from the first, disapproved of my being added to the staff) was complicated by a fundamental difference on the subject of Temperance, and towards the end of the year I saw it was impossible to continue my co-operation with him. Mr. Daniel Pratt offered to hand over his property in the Bee-Hive to me without charge, provided I would undertake to continue it in existence for six months. But this would have required a guarantee fund of $£_{3} 00$, which I endeavoured to raise in vain."

There is no reason to doubt that Potter had resented Solly's appointment, or that their different views on Temperance - since Solly was a total abstainer - helped to strain relations between them. The reference to the liquidation of Pratt's business is less straightforward, since Pratt never appeared in the bankruptcy court, and he was still in business as a printer and publisher until his death in 1873 . Presumably he was facing financial difficulties which forced him to reduce his commitments. As for the attempt to raise a guarantee fund, this is borne out by letters which have been preserved among Solly's papers. Three of them were from Samuel Morley, who, while making it clear that he was "not disposed to become a newspaper proprietor", was prepared to contribute $£ 50$. In the end, through some misunderstanding, Morley found himself paying $£$, 0 to Pratt and another $£ 50$ to Solly for use in the promotion of Working Men's Clubs. ${ }^{1}$ But by that time, the lack of support for the fund, Pratt's financial problems, and the difficulty of working with Potter, had combined to bring to an end Solly's editorship of the Bee-Hive.

${ }^{1}$ Samuel Morley to Henry Solly, 17 October and 7 December 1870 , and 3 January 1871 (Solly Collection). 


\section{VIII}

With the first issue of 1871 - less than eleven months after the muchheralded "launching afresh" - the Bee-Hive made yet another fresh start. This time, the change was far less abrupt. Apart from the disappearance of Solly's special features, and a tiny note on his departure, the main signs of change were an article by Frederic Harrison applauding working-class sympathy for the French Republic, and one by Lloyd Jones defending trade unions in more forthright terms than Solly had ever used. Lloyd Jones, one of the ablest working-class journalists of the day, now for the first time joined the ranks of the Bee-Hive's contributors; and until the very end of the paper's career, his front-page articles were to be among its most prominent features. In the next issue he demanded with equal vigour that working men should "use their new political power" in the interests of their class.

What pressures had been applied behind the scenes can only be guessed at. Although Pratt, at the next Bee-Hive Soiree, spoke somewhat ruefully of the need for "having occasionally to seek support from extraneous sources", 1 there is no evidence that any money had been raised to supplement Morley's $£ 50$. But it soon became clear that the editorship had reverted to Potter, who again combined the posts of editor and manager. Nothing more was heard of the Consulting Committee, which seems to have faded quietly out of existence. With the hindrances of the past year removed, Potter settled down to the thoroughly congenial task of wiping out the traces of Solly's influence; and although he never developed Hartwell's flair for popular journalism, he soon showed his real capabilities as an editor. ${ }^{2}$ The lay-out, which Solly had handled quite capriciously, was rationalised, and the contents soon became more attractively arranged. The new pattern of contents depended to a large extent on a constant supply of signed articles, so that one of the editor's chief tasks was to maintain contact with an increasing number of outside contributors, and to see that there were always articles available on some of the outstanding topics of the day. This Potter performed admirably. It had the further advantage, since Potter obviously wrote with less facility than either Solly or Hartwell, of lessening the need for so much of the paper's contents to be written by the editor himself.

What Potter called "Communicated Articles" - which normally

\footnotetext{
${ }^{1}$ Bee-Hive, I July I 87 I.

${ }^{2}$ Roberts states that "Potter's editorial ability seemed to have considerably deteriorated". But this view is based on the mistaken belief that Potter himself was editor, and Hartwell only "his assistant", during the mid-1 860's (The Trades Union Congress, 1868-192 1, p. 63).
} 
filled at least the first two pages - were carefully distinguished from the "Leading Articles" written by himself and occasionally by others. During the next two years, more than seventy different writers contributed to the "Communicated Articles" section. The vast majority, naturally enough, were middle-class sympathisers - including Beesly, Harrison, and their fellow-Positivist Henry Crompton - and most of their articles dealt with industrial and political matters. They were allowed the utmost latitude in putting forward their own views. Editorial policy was expressed by Potter in his leaders and by Lloyd Jones in his front-page articles. Other contributors were in no way expected to conform to this; and although many of course did so, frequently articles appeared which explicitly or by implication contradicted the Bee-Hive's editorially-expressed attitudes. Potter and Lloyd Jones sometimes endorsed what was said in the other articles, and occasionally criticised it. More often, whenever there was room for a divergence of view, the articles would be answered by other contributors in subsequent issues; and several running controversies developed in this way. The one that caused most stir was started by Beesly, whose ten articles in whole-hearted support of the Paris Commune - "the grand uprising of a patriotic population"1 - were interspersed with others from four different opponents.

This policy of making the Bee-Hive an "open forum" must have been somewhat confusing to the casual reader; but it was highly praised by some of the contributors and by other papers. ${ }^{2}$ The "Communicated Articles", which often numbered as many as seven or eight in a single issue, certainly raised the level of informed and sustained argument in the columns of the Bee-Hive to a higher point than it had ever before reached. Nor did the divergence of views in these articles mean that the Bee-Hive was without a definite policy of its own. The general tone of the paper, set mainly by Potter and Lloyd Jones, and sustained by many of the other contributors, was marked by a determined advocacy of working-class interests which contrasted almost as strongly with Solly's attitude as his had with Hartwell's. There was no attempt to return to Hartwell's sensationalism, nor would it be true to say that the old fighting spirit came back into the paper. But the Bee-Hive did reflect, and to some extent help to foster, the new militancy that grew up in the trade union movement as the boom conditions of the early 1870 's developed. That support for strikes and "forward movements" was more discriminating than in

1 Bee-Hive, Is April 1871 .

2 E.g., "It has one honourable feature among others; it admits the point-blankest answers even to its own editorial utterances" (Punch, 16 December 1871). 
the mid-1 860's, and less marred by personal abuse, served to increase rather than to lessen the paper's influence. In fact, this period saw a remarkable revival of the Bee-Hive as the national organ of the workingclass movement. It was criticised by the Republicans, and Marx still called it a "sham workers' paper"; but a more representative view was that put forward by Thomas Wright, who, in Our New Masters, compared the Bee-Hive favourably with Reynolds's, and described it as the best advocate of general working-class interests in the British press. ${ }^{1}$

With the revival of the Bee-Hive, Potter too, after his partial eclipse, came back into a position of some prominence as a working-class leader. No longer a centre of opposition to the Junta, and already a member of the ASCJ, ${ }^{2}$ the Conference of Amalgamated Trades, and the "united front" of the Labour Representation League, Potter now worked in some degree of harmony with most of his old enemies. With Applegarth and Howell, he was particularly closely associated. Applegarth was even prepared to praise Potter in public. At the BeeHive Soiree of $187 \mathrm{I}$, after delivering a speech which was in effect a statement of the Junta's support for the reformed Bee-Hive, Applegarth added: "For skill and tact, its conductor, Mr. Potter, is a match for any man in this country." 3 Now that he had come to terms with them, and had as it were purged his offences by being reduced for a time to the position of Solly's assistant, they were no doubt glad to have him on their side, and even to call on his services as chairman and orator. But Raymond Postgate's picture of Potter at this time as a "broken man", being used by the Junta "for purposes that, if at all honest, he must have thought contemptible", 4 is very far from the truth. With very little clear alternative policy of his own, he had accepted the inevitable, and acknowledged the Junta's leadership. One part of his policy, however, he had never completely given up. He was still in favour of concerted action with the provincial trade unionists through the TUC, and the launching of a nationwide campaign to secure the full legalisation of the unions. On this, the Junta in $187 \mathrm{I}$ found themselves compelled to abandon their old exclusiveness, and come round to Potter's point of view.

Although the Manchester Congress of I868 had endorsed the policy of the Conference of Amalgamated Trades, this did not mean

1 Our New Masters, I 873; chapter on "The Press and the People".

" He was elected an honorary member by the Grays Inn Road branch in June I 868 (BeeHive, 20 June 1868 ).

${ }^{3}$ Bee-Hive, I July I $87 \mathrm{I}$.

4 The Builders' History, p. 289 . Postgate is equally wrong in his comments on the general tone of the Bee-Hive during this period. 
that the provincial trade unionists were thenceforth prepared to leave the handling of the trade union case entirely to the Junta. The Birmingham Congress of 1869 decided that the next year's meeting should be held in London, preferably at the time when the government's promised Trade Union Bill was before Parliament. The small group of London delegates were asked to form a committee to co-operate with the London Trades Council in calling the Congress. Potter became secretary, and Howell took the chair at the one recorded meeting of the committee. ${ }^{1}$ When it became clear that the government's Bill would be delayed for some time, provincial leaders began to urge that Congress should still meet in London in I 870 , in order, as William Owen put it, to "express our views" to the government." But the last thing the Junta wanted was such an expression of views from the wider body of trade unionists before the Bill itself had been drawn up. Although the committee actually began making arrangements for a meeting in October, the Junta soon brought pressure to bear; and Potter and Howell had to explain that "after more matured deliberation with the representatives of the large societies", it had been decided to postpone the meeting until the Bill was actually before the House. ${ }^{3}$

The Bill was eventually introduced by the Home Secretary on 14 February i $87 \mathrm{r}$. As the Junta had hoped, it gave complete protection to trade union funds; but to their dismay it also included a lengthy clause which laid down severe penalties for "molestation", "obstruction", and "intimidation" - offences which were not all clearly defined, and which made any form of picketing virtually impossible without a breach of the law. With nothing now to be lost through concerted action, they at once set about establishing full co-operation with the wider movement. The Conference of Amalgamated Trades met on 8 February, accepted a resolution of Potter's that the Conference should hold a delegate meeting of London trade unionists the following week, decided to consult their old legal advisers, and agreed that the Congress Committee should call Congress together at the earliest possible moment. ${ }^{4}$ When Congress met, on 6 March, Potter was elected president. It was almost exactly four years since he had presided over the last national trade union conference to have been held in London - his much-criticised St. Martin's Hall Conference of 1867. This time, the circumstances were completely different. Many of the provincial leaders who had attended the 1867 Conference were

${ }^{1}$ Bee-Hive, I 3 August 1870 .

Bee-Hive, 9 July 1870 .

${ }^{3}$ Bee-Hive, 22 October 1870.

4 Minutes of the Conference of Amalgamated Trades (Webb Collection). 
again present, notably Kane, Macdonald, W. H. Wood and William Leigh, who had all served on the abortive Conference Committee. But now the Junta and their main supporters were also present in full force, and Applegarth at once endorsed the new authority of Congress by reporting to it on behalf of the Conference of Amalgamated Trades.

A highly indignant Congress attacked the "criminal clause", arranged for the lobbying of M.P.'s and a deputation to the Home Secretary, and even considered a motion that would have put the movement on record in opposition to the Bill as a whole. But while opposition to the third clause was of course unanimous, a substantial majority supported the view that this should not be allowed to endanger the benefits conferred by the rest of the Bill. The resolution eventually adopted was intended to show this, while disclaiming any responsibility in the event of the Bill being passed in its original form. A new Committee was elected to continue the agitation, this time with Howell as secretary and Potter as chairman. No members of the Junta were included; but it had already been decided that the Committee should work in co-operation with the Conference of Amalgamated Trades, which in spite of the broadening of its base was still naturally regarded as the Junta's own organisation. ${ }^{1}$ The situation was clarified on 28 March by the Home Secretary's decision to divide the Bill into two. The third clause now stood alone as the Criminal Law Amendment Bill, so that it was possible to oppose one Bill in its entirety without endangering the other. When both became law at the end of June, the stage was set for what Potter called "a tough and earnest struggle for repeal". He had already, of course, swung all the resources of the Bee-Hive into the struggle. Throughout the campaign, until the repeal of the Criminal Law Amendment Act in I875, the Bee-Hive was recognised as the organ of the TUC and its Parliamentary Committee.

During the ten months that elapsed before the next Congress, important developments in the labour movement were reflected in the Bee-Hive. Improving economic conditions generated a renewed confidence within established unions, and encouraged the spread of trade unionism to new groups of workers. By the middle of $187 \mathrm{I}$, reports of strikes and "forward movements" were swelling the columns of "trades intelligence", and Potter and Lloyd Jones were welcoming this revival of activity. The most important of these movements was the Tyneside engineers' strike for the nine-hours day. This began as

1 The Congress was fully reported in the next two issues of the Bee-Hive - II and 18 March I87I. 
an unofficial movement, and Potter was at first cautious in his comments. As soon as the ASE Executive had given its somewhat belated blessing, Potter, with Allan's full approval, convened a meeting of London trade unionists to organise support both for the engineers and also for the South Wales miners, who were striking for a wage increase. A committee was appointed to co-operate with the Trades Council in collecting subscriptions, with Potter as chairman, Odger as secretary, and Allan as treasurer ${ }^{1}$ - a grouping which gives some indication of the changes that had taken place since the days when the Junta had attacked Potter as a "strike-monger". On the political front, the most significant development was the growing working-class dissatisfaction with the Liberal government. Nonconformists had already been disappointed by the Education Act of 1870 , and trade unionists were more than disappointed with the labour legislation of 1871 . The delay over the ballot added fuel to the fire, and the Bee-Hive's comments on the government and on the Liberal party became increasingly critical. This helps to explain the curious episode of the "New Social Alliance", when Scott Russell, hoping to gain support for the Conservatives, almost persuaded a group of leading working men (including Potter, Applegarth, Guile, Howell and Lloyd Jones) to meet some of the Conservative peers and discuss a new programme of social reform. ${ }^{2}$

There was one other important development in 1871 , of which only a few indications appeared in the Bee-Hive. During the year, the Junta began to break up. Odger had become increasingly active in the Republican movement from the end of 1870 ; and the fact that none of the other members of the Junta shared his views inevitably led to some estrangement between them. In May i 871, Applegarth resigned from the secretaryship of the ASCJ, after Cremer and William Harry had pushed through the Executive Council their resolution ordering him to give up his membership of the Royal Commission on the Contagious Diseases Acts. ${ }^{3}$ Applegarth remained a member of the ASCJ, and, accepting a part-time post under the Capital and Labour Committee of the Social Science Association, he continued to take an active part in the labour movement; but he was no longer in the same position of authority. The next move came on I September, when the Conference of Amalgamated Trades was dissolved, leaving the campaign against the Criminal Law Amendment Act to be handled by the Parliamentary

${ }^{1}$ Bee-Hive, 22 July 187 I.

2 Bee-Hive, 28 October to 25 November 1871 ; Times, 30 October I871.

${ }^{3}$ For the ensuing conflict in the ASCJ see: The Builders' History, Pp. 290-292; and S. Higenbottam, Our Society's History, 1939, pp. 91-103. 
Committee. As a natural result of this dissolution, the London Trades Council - which for the past three years had been very much overshadowed by the Conference - was revived and reorganised in the following May. But at the delegate meeting which considered the reorganisation, Odger, preoccupied with Republicanism and Radical politics, resigned from the secretaryship, and was succeeded by George Shipton of the Amalgamated Painters.

Even after these changes, the Junta still wielded much influence in the trade union movement; but they no longer worked together as a closely-knit team with a common policy. As a result, their reputation has tended to be too much coloured by the events of 1867 to 1871 . As individuals, most of them showed during the next few years that they were by no means unsympathetic towards the new developments in the movement. But their activities during this time, ranging from support for the agricultural labourers' strike to Applegarth's assistance to the new Union of Builders' Labourers, have received much less attention than the caution and exclusiveness of their attitude at the time when they were pursuing a very deliberate policy for particular ends.

\section{IX}

The next Congress met at Nottingham in January i 872 . When a new Committee was elected, Potter was not included. Provincial delegates outnumbered the eighteen Londoners by nearly three to one; and by the time the elections took place, they had already shown a marked lack of enthusiasm for any of the London leaders. After it had been agreed that the next Committee should consist of nine members, the old Committee put forward nine nominations, including, in deference to the obvious feelings of the Congress, only two Londoners - Potter and Howell. Further nominations followed from the body of the Congress. All the members of the Junta except Coulson were present, but in spite of the dissolution of the Conference of Amalgamated Trades, not one of them was nominated. When it came to the voting, an almost unknown Londoner - George Thomas, a shoemaker nominated by Odger - came seventh on the list. Ninth and last, in spite of his year as secretary, was George Howell, who just scraped home with 33 votes against the 31 cast for Potter. The remaining members were all from the provinces. In the circumstances, Potter's failure was not such a complete rebuff as might appear at first sight; and it was no doubt partly due to his closer relations with the Junta, who so far had fared even worse. However, the Junta did find a way of ensuring some representation. Allan had already been elected 
treasurer to Congress, and by a separate vote it was decided that the treasurer should be added to the Committee. ${ }^{1}$

The fact that Potter had ceased to be a member did little to weaken the close tie between the Parliamentary Committee and the Bee-Hive. The detailed weekly reports, and the supporting articles and editorials, soon showed an immense amount of work being undertaken by the Committee - much of it in support of new measures to improve working conditions. But the "legislative demands" of the unions were no longer controlled by the Junta; and the difference in attitude was clearly demonstrated by a controversy which broke out in May, when Vernon Harcourt undertook to introduce a Bill amending the Criminal Law Amendment Act. The Committee at this point was completely dominated by Macdonald and Howell - who had been elected chairman and secretary respectively at the Committee's first meeting - since Allan was ill and often absent from meetings, and most of the others were being consulted by post. Macdonald and Howell allowed themselves to be persuaded by Mundella, Harcourt, and another lawyer M.P., Henry James, that this should be the next move; but Harrison and the Cromptons were not consulted. As soon as the news became known, Beesly and Harrison protested in articles in the Bee-Hive, arguing that the Bill would produce only a very slight improvement, and if introduced with the backing of the Parliamentary Committee, would be much harder to repeal. They returned to the attack in subsequent issues, while Howell wrote two articles in reply, and Harcourt himself explained his motives. Potter disapproved of the Committee's action, and allowed Harrison to name him as one of those who saw the dangers of this move. ${ }^{2}$ But Potter was not prepared to say so himself, and he took no part in the controversy, opening the columns of the Bee-Hive impartially to the Parliamentary Committee and to their critics. ${ }^{3}$ Although Harcourt's Bill received little support in the House, and was withdrawn in July, the whole matter was hotly debated once more at the Leeds Congress in January I 873. Some delegates, including Odger, were highly critical of the Committee's attitude, and Congress reaffirmed its decision that the aim must be total repeal. Potter let it be seen that he agreed with the

\footnotetext{
1 Bee-Hive, I3 and 20 January 1872; Nottingham Daily Guardian, I 3 January I872; Nottingham Daily Express, is January 1872 ; Minutes of 1872 Congress (Howell Collection).

${ }^{2}$ Harrison also named Allan, who obviously had misgivings; but Howell persuaded Allan that he must stand by the Committee, even though he had played very little part in the proceedings, and had not been fully aware of what was taking place (Parliamentary Committee Minutes (Howell Collection), 6 June 1872 ).

${ }^{3}$ Bee-Hive, 31 May to 28 June 1872.
} 
critics, but he carefully refrained from attacking the Committee, and in the end it was Potter who moved the adoption of their report. ${ }^{1}$

This Congress elected a stronger and better balanced Committee, which included Odger and Guile as well as Allan. Potter was not nominated; but his allegiance to the Committee remained unchanged. This was the reason why no attempt was made to re-establish the old close connection between the Bee-Hive and the London Trades Council - in spite of the great increase in the Trades Council's activities since the reorganisation, and the ending of the quarrel which had led to the "excommunication" of the Bee-Hive in 1865. Many Trades Council members felt strongly that the Council should again exercise the authority that had been built up in the mid-sixties; and they resented the fact that the mantle of the Conference of Amalgamated Trades had descended upon the Parliamentary Committee. In London, there was still much suspicion of the good sense of the provincial members who figured largely on the Committee, but this no longer took the form, as it had with the Junta, of holding aloof from the provincials because a more militant attitude might prejudice their case. Indeed, the first open opposition was the Trades Council's repudiation of the Committee's readiness to compromise in $\mathbf{1 8 7 2 . 2}$ In 1874 the position was to be reversed, with the Trades Council willing to compromise, and the Parliamentary Committee - including more of the London leaders than its predecessor of 1872 - making a firmer stand. There was, in fact, no clear-cut divergence of policy between the two bodies. Primarily, the question at issue between them was one of power and authority within the movement. The difference of opinion in 1872 was followed by a proposal from the Trades Council that the Parliamentary Committee should be disbanded, and provincial delegates should be appointed to sit with the Trades Council as the national body. ${ }^{3}$ Even as late as 1875 , after the labour laws of that year had been passed, there was some support at a Trades Council delegate meeting for a motion that the Parliamentary Committee could be dispensed with now that it had done its work.4

The remaining members of the Junta had no agreed policy on this matter. Coulson, who never became a member of the Parliamentary Committee, took the lead in urging the Trades Council's claims. Allan and Guile were more concerned with the work of the Committee,

${ }^{1}$ Bee-Hive, I 8 January 1873.

${ }^{2}$ Meeting under the chairmanship of Odger, they passed a unanimous resolution condemning the action of the Committee (LTC Minutes, 25 June 1872).

${ }^{3}$ LTC Minutes, 20 December 1872.

4 LTC Minutes (Delegate Meeting), 22 September 1875. The motion was defeated after being "strongly opposed" by Odger. 
and regarded the Trades Council as a useful but in the last resort a subordinate body. Odger, now active on both bodies, argued that each had its place, and that the important thing was to "avoid clashing", as he put it at one meeting, through agreement on some division of functions. ${ }^{1}$ As for Potter, his chief concern during the early stages of the dispute was to remain as nearly neutral as possible. But his first loyalty now was to the Parliamentary Committee; and this was unmistakably demonstrated in I874, when the newly-elected Conservative government set up their Royal Commission on the labour laws. This delaying move was greeted with angry derision in the Bee-Hive, and the Parliamentary Committee, called together by telegram, recommended to all trade unionists that they should refuse to give evidence. ${ }^{2}$ The Trades Council, in spite of Odger's opposition, took a different view; and before the Parliamentary Committee met, the Trades Council had formally welcomed the new investigation. Potter thereupon threw overboard his policy of avoiding any direct attack on the Trades Council, and his next three editorials can be read as a manifesto on the respective positions of the Parliamentary Committee, the Bee-Hive, and the London Trades Council, in the national organisation of the trade union movement.

"Nothing can be more clear than that the initiative ought to have been left to the Parliamentary Committee, legally and properly appointed by Congress... What higher authority can exist in the great labour movement?... There must be discipline and subordination if the great struggle now going on in the interest of labour is to end in victory."3

Meanwhile, the trade union revival had continued with redoubled vigour in the boom conditions of $1872-3$. "The spirit of Unionism is taking possession of all sorts of employed persons", wrote Potter exultantly on 4 May i 872 ; and the Bee-Hive set out to chronicle and assist the spread of organisation. The cause supported with most fervour was that of the agricultural labourers, whose sudden appearance on the trade union scene had become a national sensation by the summer of 1872. Many London trade unionists (including Guile, Applegarth and Odger) gave generous assistance to the farm workers, but by far the most active was Potter, who, addressing meeting after meeting in the rural areas, proved himself a most effective recruiting agent. ${ }^{4}$

1 Bee-Hive, 26 July 1873.

${ }^{2}$ Macdonald, who rashly accepted a seat on the Commission before there had been time for consultation, was forced to resign from the chairmanship of the Parliamentary Committee.

${ }^{3}$ Bee-Hive, 2I March to 4 April 1874.

"When London support showed signs of slackening, it was Potter who organised the 
This and similar movements gave to the Bee-Hive for some months an air of excitement that was at least faintly reminiscent of the great days of 1865 . But by the middle of 1873 the first signs of the coming depression were beginning to show themselves, and by 1874 trade unionists, as Lloyd Jones continually pointed out, were faced with the problem of adapting their organisation and their attitudes to meet the threat of steadily worsening economic conditions. Potter by this time was strenuously supporting the views he had once attacked. Not only did he echo Lloyd Jones's praise of the "amalgamated principles" of high friendly benefits and centralisation, but he also took a very firm line on the need for "discipline and subordination" whenever sectional movements threatened the leadership of any union. Later, when it had become still more necessary to look afresh at basic principles, Potter wrote an editorial laying down the conditions that ought to be fulfilled before any strike deserved support - "full sanction of the governing body", and "adequate efforts to secure a peaceful settlement". 1

In politics, the Bee-Hive during these years continued to warn the Liberals that they must mend their ways if they expected workingclass support at the next election. Beesly in particular missed no opportunity of arguing that candidates' views on the labour laws must be the sole test, irrespective of party labels. This was the central argument in all the Bee-Hive's political comment up to the general election of February 1874 ; and in this the paper was completely in line with the policies of the Labour Representation League and the TUC. It was in fact Potter who moved the resolution to this effect which was passed by the 1873 Congress. The accompanying demand that working-class candidates must stand wherever they had a chance of success, even at the risk of splitting the vote, suggested at times a further advance. The League's I 873 manifesto talked of organising "a great Labour party" - largely due to Latham, who, in the last few months of his life, was urgently pressing the view that "it was time the working classes should form a party of their own". ${ }^{2}$ Lloyd Jones had already urged Liberal working men to form their own "advanced party"; and on the eve of the election Harrison called for "a real Labour party... in the constituencies and in the House". ${ }^{3}$ Potter himself stood at Peterborough, as "Working Men's Candidate" and "Labour candidate", against Liberal opposition. But after the Con-

great Exeter Hall meeting which gave a new impetus to the movement. Samuel Morley took the chair. (Bee-Hive, 14 December 1872 ).

1 Industrial Review, 23 June 1877.

${ }^{2}$ Bee-Hive, I, 22 and 29 March 1873.

${ }^{3}$ Bee-Hive, 7 December 1872 , and 31 January 1874. 
servative victory, this more independent attitude soon died away. The Liberals in opposition - especially after the 1875 legislation and the damping down of trade union activity - seemed to most of the union leaders to be their natural allies.

Before the onset of the "great depression", the Bee-Hive had undergone its final change of ownership. In March I 873, another new series was started. Plans for future improvements were announced with a flourish; and certainly the conditions of the time seemed favourable to the paper's prospects. The main innovation was the first of a series of Labour Portraits - outline biographies, each illustrated with a head-and-shoulders portrait - and these were to prove a highly popular feature. ${ }^{1}$ But within a fortnight came news of the sudden death of Daniel Pratt. His obituary, in which for the first time readers were told in so many words about his proprietorship, paid tribute to his "substantial aid"; and the Bee-Hive was immediately reduced in size from $x 6$ to 12 pages. Pratt died intestate, and Letters of Administration were granted to one of his relatives. The subsequent negotiations are obscure, but by 7 July the paper had become Potter's property, and he re-registered it for the second time at Stationers' Hall, once more naming himself as "proprietor of the copyright". Meanwhile, the pages of the Bee-Hive showed, week by week, a gallant but increasingly unsuccessful attempt to live up to the promises made in the announcement of the new series. To the handicap imposed by the loss of a quarter of its space was soon to be added a new threat to the circulation, as the economic climate changed. For Potter, the task obviously involved a closer concentration on the running of what was at last his own paper, and a corresponding decrease in the time available for outside activities. It is true that he took on a fresh set of responsibilities in November 1873, when he finally achieved his ambition of representing Westminster on the London School Board; but this alone would not have accounted for the contrast with his previous record as an organiser and "agitator". In 1874 , and again in 1 875, he even refused nomination for the Parliamentary Committee, on the grounds of "pressure of work". ${ }^{2}$

Potter remained editor-proprietor throughout the last years of the paper's life. At the beginning of I875, another major change was introduced, when the whole format was adjusted to the pattern recognised by contemporaries as that of a review rather than a news-

I In September 1873 , Potter published the first twelve as Volume I of the Bee-Hive Portrait Gallery. This was followed by a second volume in November I 874. Priced at I/-each, these volumes were still selling well some three years later.

2 Bee-Hive, 24 January 1874 , and 30 January 1875 . 
paper. Two years later, the title itself was brought into line, and from then until the end of 1878 the Bee-Hive appeared as the Industrial Review, once more at the old price of twopence. These were years of fairly steady decline, which matched the decline in numbers and in vigour of the labour movement as a whole. New men were now taking over the leadership - men such as George Shipton of the London Trades Council, J. D. Prior, who had succeeded Applegarth as secretary to the ASCJ, John Burnett, who became secretary to the ASE after Allan's death in 1874 , and Henry Broadhurst, who, already secretary to the Labour Representation League, became also secretary to the Parliamentary Committee when Howell resigned in I 875. They were lesser men than the Junta; and although they paid tribute to the Junta's achievements, and made some attempt to continue their policies, they were dealing with a situation in which they were forced on to the defensive. Their easy acceptance of a "Lib-Lab" attitude comes out clearly in the preamble to the League's i 875 policy statement - "We have ever sought to be allied to the great Liberal party, to which we, by conviction, belong..."1 The Bee-Hive followed suit. Lloyd Jones, it is true, still showed signs of hankering after some working-class independence in politics; but Potter soon set out to prove himself a "good Gladstonian Liberal". The corresponding change in industrial policy came more slowly. By i 880, the tendency throughout the leadership would be to avoid disputes at all costs. But the last years of the Bee-Hive, and the two years after the change of title, were full of strikes and lock-outs; and it was in fact the record of continual defeats during this period that dictated the policy of the next few years. For the paper, too, the retreat on the industrial front was a fighting retreat. But whatever policies were being advocated, the circulation and advertisement revenue could not be kept up. The number of signed articles dwindled, "trades intelligence" fell away, and "scissors and paste" methods were increasingly used to fill out the contents. Towards the end, Potter was trying to build up a general publishing business that would not be dependent on one newspaper. With the issue of 28 December 1878 , the Industrial Review closed down; and Potter became bankrupt. ${ }^{2}$

There was nothing spectacular about Potter's later career. He was soon back in business as a publisher, bringing out a constant stream of cheap novelettes, political tracts, and short biographies of leading

1 In the Howell Collection.

${ }^{2}$ For reports of the bankruptcy proceedings, see: Reynolds's Newspaper, 23 and 30 March 1879; 'Times, 29 March 1879; Peterborough Advertiser, 29 March 1879; and Spalding Free Press, I and 8 April 1879. 
politicians - some of which he wrote himself. His most important public appearance was his last attempt to become a Member of Parliament, when he stood as an official Liberal candidate at Preston in 1886 . He had remained a member of the London School Board until 1882 ; and in 1884 he had restarted the LWMA. But the revived Association made far less stir than its predecessor, and the one surviving annual report, and resolutions sent to the press, show it as little more than a social club supporting "Lib-Lab" policies. ${ }^{1}$ There is no record of Potter's views on the growing Socialist movement of the I 880's, or the "New Unionism" of the less skilled workers at the end of the decade. But it is highly unlikely that he looked on these movements with any more favour than did Howell or Broadhurst. Certainly, judging from comments in the Labour Elector, the leaders of these movements had no respect for Potter. ${ }^{2}$ In his later years he seldom even showed any leanings towards the Radical wing of the Liberal party; and as early as I $88 \mathrm{I}$ he was being described by Radicals as a "staunch Whig". ${ }^{3}$ Within this framework, he kept up his interest in public affairs. Still in business as a publisher, he continued to attend meetings and write letters to the press until shortly before his death in 1893 .

\section{$\mathrm{X}$}

The two oldest members of the Junta, Allan and Odger, had died before the Industrial Review closed down - Allan in I874, and Odger in 1877 . Guile died in 1883 , and Coulson in the same year as Potter. But Applegarth, just two years younger than Potter, was still alive and vigorous; and he was in fact to live on until 1924. Five years after Potter's death, Applegarth read a paper to the Hotspur Club - an association of North-country engineers working in London - with the title "People I Have Known". 4 Almost all the men he introduced were old comrades, whom he recalled with admiration and sometimes with affection. Of only one man had Applegarth any harsh words to say. This one, introduced as "the King of Quacks", was left unnamed; but there can be no doubts about his identity. In spite of the reconciliation at the beginning of the I870's, Applegarth still remembered Potter as the man who had opposed him. His "King of Quacks" is matched by his comment to the Webbs when they were collecting the material for their History - "a fraud from the first". ${ }^{5}$

${ }^{1}$ A copy of the 1888 Annual Report is in the Howell Collection.

${ }^{2}$ Labour Elector, I9 October 1889.

${ }^{3}$ Herbert Burrows, in the Radical, 26 November I88I.

"Applegarth's typescript is in the Howell Collection.

${ }^{5}$ The Webbs' Ms. "Notes on Trade Union Leaders" (Webb Collection). 
Looking at the situation of the mid-sixties, it is impossible not to sympathise with Applegarth's point of view, even if his later attitude strikes one as uncharitable. Potter had been thrust by circumstances, as much as by his own abilities, into a position of leadership which he was unable to sustain. The establishment of the Bee-Hive increased his belief in his own powers; and there can be no doubt that he thoroughly enjoyed his early notoriety, and resented the emergence of rival leaders of a different type. Odger was fully justified when he told the Trades Council delegates in 1865 that Potter wanted "all power and all control".' Although Potter's early opposition to Applegarth was supported by men who were far from being mere nonentities, easily swayed by the oratory of a "quack" - including Guile until the interests of his union brought him into the Conference of Amalgamated Trades, and Dunning throughout the quarrel - it was still mixed with motives of personal aggrandisement, as well as being based on an inadequate conception of trade union needs. Nevertheless, Applegarth's contemptuous dismissal of Potter, which so influenced the Webbs, certainly does not give the whole of the picture.

It is easy to see, from the vantage-point of the present day, that the Junta's policy was more in accordance with the needs of the trade union movement than anything Potter had to offer. But it does not follow that they were always right and Potter was always wrong. The core of their policy - the insistence on building up centralised national unions, moderate in outlook and using the strike weapon sparingly, while discriminating over strikes to be supported in other industries was soundness itself, in spite of their sometimes autocratic methods. If the whole trade union movement had followed Potter's early line, the result could only have been anarchy within the movement, and an indefinite postponement of the unions' legal and industrial recognition. In fact, on this aspect of the Junta's policy, Potter was never able to put up a reasoned argument against them, and he could only try to assimilate his policy to theirs. But in the exclusiveness of their attitude from the time the Royal Commission was set up in 1867 , the Junta were on much weaker ground. Although in 1867 , having missed the chance of calling a national conference themselves, they could argue plausibly that joining a movement led by Potter would damage their case, and in the changed situation of the following year they did accept the co-operation of those London unions that had supported Potter, their attitude towards the provincials was maintained even after the 1868 TUC had endorsed the policy of the Conference of

${ }^{1}$ Report of LTC Delegate Meeting, 6 April 186s (LTC pamphlet, Mr. Potter and the London Trades Council, in the Howell Collection). 
Amalgamated Trades. They gained nothing by it; and by the time they came round to Potter's point of view in 1871 , they had provoked a resentment among provincial trade unionists that helped to reduce the Junta's own effectiveness in the next phase of the struggle.

It was during this next phase that the change in Potter's position was clearly demonstrated. He had been moving towards acceptance of the Junta's leadership since I 868 - partly of course through the need for Pratt's financial assistance to keep the Bee-Hive solvent, but also through the recognition that his own attempt at leadership had failed. At the end of I 869, he could do nothing to avert the humiliation of Solly's appointment; and by the beginning of $x 871$, when with the Junta's approval he was reinstated as editor, he had been taught a severe lesson. He was not a "broken man" - "chastened" might have been a better word - but he was no longer an opponent of the Junta, and apart from the question of relations with the TUC he had come to accept their views. It was then only a matter of weeks before the Trade Union Bill forced the Junta to modify their attitude towards the TUC. With this change, their policy and Potter's became for all practical purposes identical.

In the same year, the Junta began to break up; and from Potter's point of view, it was something of a tragedy that this should have happened so soon after he had come to terms with them. If they had still worked together as a team, then in all probability Potter, working with them, would have been able to make a far more effective contribution to the development of the labour movement. As it was, he continued to co-operate with individual members of the group, and he played a useful if not particularly distinguished part in the struggles of the early 1870's. But he had committed both himself and the BeeHive to support of the Parliamentary Committee as the national trade union leadership; and by the time members of the Junta came to have any appreciable influence on the Parliamentary Committee, Applegarth was no longer with them, and they had ceased to work to a common policy. The dispute of 1872 showed up the drawbacks of the position in which Potter had placed himself. In that year, Howell and Macdonald showed themselves far more ready to compromise over the Criminal Law Amendment Act than the Junta would have been. Potter, disapproving of their actions but unwilling to oppose the Committee, could do no more in the way of protest than to open the columns of the Bee-Hive impartially to either side in the controversy that developed.

However, until the last days of the Industrial Review, Potter continued to advocate the essentials of the Junta's policy. After 1873 , with the early stages of the depression following closely upon his assump- 
tion of increased responsibilities as proprietor of the Bee-Hive, he was less active in the labour movement. But in the Bee-Hive itself, and then for two years in the Industrial Review, his influence was consistently brought to bear in support of "amalgamated principles", a more responsible attitude towards strikes, and discipline within unions. During this period, having ceased to be a rebel, and moved over into the ranks of those who stood, somewhat self-righteously, for discipline and correct behaviour, he naturally appears to the historian as a less interesting and glamorous figure; and this part of his career has accordingly received far less attention in histories of the movement. But his industrial policy during the I 870 's, though it had of course its limitations, was sounder than the policy of his earlier phase. If Potter is to be condemned, as the Webbs condemned him, for opposing the Junta during the 1860 's, it should at least be remembered that at the beginning of the following decade he was working in harmony with them, and that long after the Junta had broken up he was still strenuously advocating the main principles on which their policy was based.

To summarise the major developments of Potter's career in this way is of course to treat him primarily as a trade unionist. It is true that he was also active in politics; but at least until the last few years of his life he was always, as an American interviewer noted in $187 \mathrm{I}$, "a trade unionist rather than a politician". ${ }^{1}$ However, his political views and actions do help to explain his development. What stands out, when Potter's career is taken as a whole, is the total lack of any coherent social or political philosophy as a basis for his actions. This was in fact his greatest weakness. From the standpoint of Marx, or from that of the Positivists, it was a weakness shared in varying degrees by all the leading trade unionists of the period. But Potter, especially in his early days, was peculiarly vulnerable to criticism on this score. While the Junta were consciously adapting their unions to the conditions of their time, Potter was opposing them with a policy which, while still unlikely to have achieved any success, might at least have been defended if he had been a revolutionary Socialist, or had held views akin to those of the Syndicalists of a later generation. In all that he said and wrote, there was never the slightest hint of any such views.

Postgate, who did grasp much of the significance of Potter's more militant period, was perfectly correct when he said: "It is easy to be misled and see in Potter and his followers class-conscious workers of

${ }^{1}$ Interview with a correspondent of the New York World, quoted in the Eastern Post, 28 October 1871 . 
the modern type, fighting a class war and knowing it... They were nothing of the sort... No clear-minded revolutionaries supported Potter".. So far was Potter from being a revolutionary of any type, that in politics he normally stood well to the right of his early opponent, George Odger. Unlike Odger, he was never a member of the International, or of any of the Republican groups, and he soon turned away from the Land and Labour League in order to give his full support to the much more respectable Land Tenure Reform Association. In the days of the nine-hours movement, he had shown a complete indifference to Radical politics. ${ }^{2}$ Then followed the period when he accepted and defended Troup's pro-Southern views. He did allow himself to become indentified with Hartwell's advocacy of trade union political action, and he certainly became prominent in the Reform movement after 1865 ; but he was already hesitating over independent labour representation before Hartwell attempted to stand for Stoke in I 868. When Potter eventually made a firm stand on this question, during the period which culminated in the 1874 election, it was at a time when the whole trade union leadership had become disillusioned with the Liberals. Thereafter, he rapidly reverted to a "Lib-Lab" position; and the moderate Liberalism of his later years was the natural attitude of an ageing man who had never really seen anything incompatible between middle-class Liberalism and workingclass interests.

This point is essential to an understanding of Potter's career. Without it, he can easily be seen not only as a "class-conscious worker ...fighting a class war", but also as one who was then "bought off" by his middle-class opponents. His honesty was of course often questioned; and some of the accusations would support such a view. Marx declared in 1865 that the middle classes could "smell his venality", and Mundella said in 1871 : "Potter is a humbug, and lives pretty much on doles". ${ }^{3}$ But none of these accusations was ever proved. As for "living on doles", if Potter had left us copies of all his letters, as Howell so incautiously did, these might tell something of the same story of Liberal "doles" gratefully accepted and still more frequently solicited. In Potter's case, there is no such evidence available; and

1 The Builders' History, pp. $195-196$.

2 He was amazed by the anger of some of the old Chartists when he invited Lord Robert Montagu - a fanatical opponent of any extension of the franchise - to address one of his meetings (Reynolds's Newspaper, 8 July to S August 1860 ; Morning Star, 2, 12 and 16 July I 860).

${ }^{3}$ Marx to Engels, 9 May I 865 (MEGA, Vol. III, p. 268); A. J. Mundella to Robert Leader, 18 October 1871 (quoted by W. H. G. Armytage in his A. J. Mundella, 1951, p. 99). 
some of Howell's letters actually show up Potter in a much more favourable light. In one, for instance, Howell complained bitterly that Potter had committed them both to tour the country on behalf of the Working Men's Committee for the Separation of Church and State, without making sure in advance that the Liberation Society would pay them for their services. ${ }^{1}$ However, this cannot of course be taken to mean that Potter never received payment from Liberal sources, or that he was never influenced by the possibilities of such payment. His changing attitude from 1868 was certainly influenced by the Bee-Hive's dependence on Pratt's financial aid; and the Bee-Hive's support for the Liberals at the 1868 election was offered as a straightforward return for contributions to the "circulation fund". But since Potter had never held any kind of left-wing political views, it was not really necessary to bribe him in order to turn him into a "Lib-Lab". As with the increasing moderation of his industrial policy, his lack of a coherent philosophy left him with no alternative.

It was quite in keeping with this that Potter should have been ineffectual as a policy-maker. He seldom initiated any policy, even though the vigour of his advocacy often made it appear that he had done so. The nine-hours movement itself was a revival of an earlier demand; while his industrial militancy in the mid-sixties was simply a continuation of what was rapidly becoming an old-fashioned attitude, reinforced by his eagerness to lead the way in supporting every group of workers involved in a dispute. His views on the American Civil War were taken over from Troup, those on trade unions and politics from Hartwell. Later, he was to advocate Pratt's views on emigration and education. In the same way that his support for independent labour representation was a reaction to special conditions, so his concern for the organisation of the unskilled developed only in the boom period when these workers were being brought into the movement, and soon faded when conditions changed. In the 1870 's, the basis of his industrial policy was what he had learned from the Junta; and much of his writing during this period was an endorsement of Lloyd Jones's views. Even his support for the newly-formed TUC - the one item in his earlier policy which shows up to advantage against the Junta's narrowness - could be explained in terms of an emotional preference, influenced by the provincial contacts he had taken pains to build up, and the widespread circulation of the Bee-Hive.

The list of Potter's weaknesses adds up to a formidable indictment. Nevertheless, he had some outstanding abilities; and it goes without

${ }^{1}$ George Howell to George Potter, 28 October I $87^{1}$ (George Howell's Letter Book). 
question that, however often these abilities were misused, there were still many occasions when Potter's activities did serve the best interests of the labour movement. Although he was apparently incapable of profound thought, he was certainly intelligent at a superficial level. He had a ready tongue, the power of making quick decisions, a vast store of energy, and often a good eye for tactics. On the platform, he could expound a given policy with force and clarity, in terms that made sense to the ordinary man; and he could do it in such a way as to win passionate support from his audience. His gifts were in fact those of the agitator rather than the organiser, the orator rather than the writer. He was probably at his best during his campaign on behalf of the agricultural labourers in 1872 , when he could concentrate on bringing members into the union, leaving the actual task of organisation to others. His writing was most effective when he was using the orator's methods. He could strike off a vivid phrase in homely and forceful language, hammer home a point by repetition; but his style too often became turgid and clumsy in any sustained argument. However, he did evolve a style that was reasonably adequate for the purposes of weekly journalism. And as editor, recognising that he was not the kind of man who could impose his personality upon a paper, he had the sense to adopt the "open forum" method, with its pages of controversial signed articles, which contributed greatly to the BeeHive's revival in the early 1870 's.

In his later years, Potter firmly believed that he had a number of worth-while achievements to his credit. Although the central point in his career was his defeat by the Junta, and his achievements were more limited than he realised, this belief was not altogether unjustified. The exaggerated self-confidence that grew out of his work for the Building Trades Conference should not be allowed to obscure the real value of that work. As president of the LWMA, he made a contribution to the Reform movement, and his influence was particularly important in bringing the London unions into full participation. He helped to establish the TUC; and during the outburst of activity in the early I 870's, when he had given up his pretensions to leadership and his support for sectional movements, he played his part as one of the men who worked for the extension and consolidation of trade unionism, and for satisfactory labour legislation. He was also - since Lucraft completely failed to make his mark - the first effective workingclass member of the London School Board.

But Potter's greatest achievement was of course the Bee-Hive itself. Without him, the paper would never have been started; and without his efforts, it would probably not have survived for more than a short time. Other factors certainly contributed - Hartwell's editorship in 
the mid-sixties, Pratt's money at the end of the decade; but from the early days of the Trades Newspaper Co. to the period of Potter's own proprietorship, it was mainly Potter's resourcefulness and his persistent hard work that kept the paper alive. If the two years of the Industrial Review be included - and it was in all essentials the same paper - the Bee-Hive ran for just over 17 years and 2 months. For a working-class newspaper of those days, it was an extraordinary span of life. The Workman's Advocate-Commonwealth lasted for less than two years after it was taken over by the Industrial Newspaper Co., and even if it is regarded as the same paper which Towers had started as the British Miner, this adds only three more years to its tally. Among contemporary newspapers with comparable claims to be working-class organs, only the Glasgow Sentinel, with its record of 27 years, ran for a longer period than the Bee-Hive, while next on the list is the Potteries Examiner, which came within a fortnight of completing its seventeenth year. ${ }^{1}$ It is true that throughout the long history of the Bee-Hive, the circulation almost certainly never exceeded the highest recorded figure - the "upwards of 8,000" reached in March and April I 865 ; and during most of the time the figure would have been far below that level. But the Bee-Hive's influence was out of all proportion to its circulation. Thomas Wright stressed this point in 1873 , when he noted that it was read and discussed by the most thoughtful and influential section of the working class; and although in Hartwell's time Wright would have seen less of a contrast with the sensationalism of Reynolds's, he could still have made much the same comment at almost any stage in the Bee-Hive's development.

It could of course be argued that there were times when the existence of the Bee-Hive was positively harmful to the labour movement - the period of 'Troup's pro-Southern policy, the time when the attacks on the Junta were splitting the London movement, or the queer interlude when Solly set the tone of the paper. Against this, it must be remembered that even at such times the Bee-Hive carried much useful information on trade union affairs, and it was very seldom, except during some spells of Solly's editorship, that any issue appeared without some sound contribution on policy matters. Taking the BeeHive's value at its lowest level, it was always a powerful trade union recruiting agent. This was perhaps less marked during the later phases than in the earlier years, when Hartwell's treatment of the

\footnotetext{
${ }^{1}$ Both of these had the advantage of being primarily local papers, the Sentinel published in a large city, the Examiner serving the needs of an isolated population with a highlydeveloped sense of community. Reynolds's was not strictly comparable, since it was never under the control of working men.
} 
general news gave it a wider circulation among unorganised workers; but through all its changes of policy, it was never possible to read the Bee-Hive without being impressed by the view that working men ought to belong to their appropriate unions. Those who said, in letters to the editor and at shareholders' meetings, that they had been persuaded to become trade unionists through reading the Bee-Hive, must have been representative of a much larger number who had undergone the same experience. Looking at the question in more specific terms, a list of the unions that at one time or another had reason to be grateful for the Bee-Hive's services would include a very high proportion of all the contemporary unions; and these services ranged from publicising their activities, through support for particular unions in disputes, to those outstanding cases where funds were collected to supplement their own resources. Equally important, though less tangible, was the Bee-Hive's contribution to the building up of a national movement. When Potter started the paper, even the London Trades Council was in its infancy, and there was really nothing to link the unions together at a national level. While it would be absurd to claim for the Bee-Hive any large share of responsibility for the development that took place during its lifetime, that development was undoubtedly influenced by the paper - not only through its constant support for the TUC, but also through the very existence of a national newspaper that treated all trade unions as part of one movement. The columns of "trades intelligence" kept trade unionists in touch with what was happening in other trades and other areas; the editorials and articles, even when advocating mistaken policies, still assumed a common interest and the need for concerted action.

Like Potter himself, the Bee-Hive was almost always concerned primarily with trade unionism. But other working-class organisations - the Co-operatives, Working Men's Clubs, and Friendly Societies often received a good deal of attention; and political movements in particular were never pushed far into the background. The Bee-Hive's outstanding contribution to working-class political development was its continued insistence that trade unionists must be politically active, and must swing their unions as organisations into the political struggle. When it came to defining the objects of this political action, the Bee-Hive was often disappointing, even in the mid-sixties, to those on the left of the movement; and the change that came over its political outlook went further than the change in its industrial policies. Even when the paper was declining into the feebleness of its last issues, Potter and Lloyd Jones were still urging working men to strengthen their unions as "fighting organisations", in order to resist the attacks on working-class standards of living. But their political comments 
could scarcely have been mistaken for Hartwell's. Under Hartwell's editorship, the Bee-Hive was certainly not revolutionary in its politics; but he brought to his task much the same attitude that he had developed during Chartist days, so that the reader was always being reminded of the aim of manhood suffrage, and the prospect that sweeping changes in society could then be brought about by the enfranchised working men. This set the tone, even though the nature of these changes was usually rather vague, and when definition was attempted they often appeared less sweeping. Within a few months from the enfranchisement of the urban workers, the "arrangement" with Pratt was already affecting the tone of the paper; and Hartwell's departure soon followed. After that, the Bee-Hive's political aims tended to become narrowed down to specific reforms, limited in scope, which might conceivably be achieved through political pressure. This tendency was of course exaggerated during the Solly period, when the Junta had in fact over-reached themselves in their attempt to find a suitable editor. Potter, from the time of his reinstatement in $187 \mathrm{I}$, seems to have taken as his guide those objects that were acceptable to the leading members of the Parliamentary Committee. Until at least i 875, some articles - especially those contributed by the Positivists did take a broader view. But once the labour laws of 1875 were on the statute book, there was nothing to prevent Potter's preference for "Lib-Lab" policies from asserting itself; and Lloyd Jones, while showing signs of deploring this development, could offer nothing constructive in its place.

The changes in the Bee-Hive's outlook were accompanied by corresponding changes in ownership, in the nature of its contents, and in the very appearance of the paper. In the days when working men were voteless, with their unions weak and of doubtful legality, it was a newspaper aiming at a wide popular appeal. By the time the urban workers had been granted a share of political responsibility, and a much stronger trade union movement had attained both legal recognition and a clear objective through the $187 \mathrm{I}$ legislation, the Bee-Hive had become much less of a newspaper and much nearer to a journal of opinion. At the start it was owned by the unions and the predominantly working-class shareholders who made up the Trades Newspaper Co., holding their regular shareholders' meetings and electing their Board of Directors. By the 1870 's this had been replaced by the proprietorship of an individual, first Daniel Pratt and then Potter himself. In format, the paper became, with each change, more like those contemporary journals that were normally called reviews; and this was eventually recognised in the change of title. One aspect of these changes may appear paradoxical - Potter, as editor allowed 
a free hand by Pratt, and even as editor-proprietor, was far less ready to give a lead to working-class opinion than was Hartwell, employed by the Trades Newspaper Co. and responsible to its Directors. The explanation lies partly in the respective characters of the two men, partly in the existence during the seventies of the Parliamentary Committee as the recognised national leadership; but above all in the fact that whereas Potter was prepared to support Hartwell when they stood together in opposition to the Junta, he was determined during his own editorship to avoid any appearance of again splitting the movement.

The Bee-Hive is of course indispensable to the historian. To read through the surviving copies from beginning to end is in fact an extraordinary experience, bringing the reader into the most intimate contact with the labour movement as it developed from week to week during a great formative period. No doubt this was on Potter's part a quite unwitting service to posterity, but that is no reason for withholding our gratitude; and in any case, the Bee-Hive's value to the historian is a measure of the extent to which contemporary readers were kept in touch with news of the movement and the opinions of some of the leading figures. But with a paper that underwent so many changes, it is very difficult to reach a concise judgment on its contemporary value. When the Webbs, in spite of their attitude to Potter, described it as "the best Labour newspaper which has yet appeared", they must have realised that they were begging a number of questions. They may not have intended, when they allowed this to stand in their 1920 edition, to rank the Bee-Hive higher than say the Clarion, or Lansbury's Daily Herald; but even in 1894 , they made no claim to have worked through all the available copies, or to have compared the Bee-Hive with every other publication that could claim to be a Labour newspaper. There were actually periods of its existence when it would compare very badly with others; and one could take issues from 1870 , or the last months of 1876 , to say nothing of the final issues of the Industrial Review, and make a claim for the Bee-Hive as one of the worst Labour papers. Nevertheless, the Bee-Hive during its best periods was by any standard a remarkably good paper. Under Hartwell, and in a quite different way under Potter while he was able to find enough outside contributors, it was skilfully edited. While articles and editorials were often of course pedestrian stuff, a surprisingly large number could be quoted as examples of effective writing; and Hartwell's fierce indignation, Beesly's combination of vigour and elegance, Lloyd Jones's grasp of detail and sound common-

1 History of Trade Unionism, 1920 edn., p. $298 \mathrm{n}$. 
sense, were qualities that merited a much more numerous readership. But in the last resort, the Bee-Hive must be judged in terms of its services to the labour movement of the I $860^{\prime}$ 's and $70^{\circ}$ 's. On this count, the value of its industrial and political news and comment, throughout its history, undoubtedly outweighed by far the criticisms that could justifiably be levelled against particular aspects of its policy. Others besides Potter must share the credit for this; but the paper was his creation, and his main concern during most of its lifetime. Potter deserves to be remembered, not just as the man who at one time led the opposition to the Junta, or even as the opponent who eventually came to terms with them, but still more for the sustained effort which for more than seventeen years he devoted to the Bee-Hive. 